\title{
Lumen
}

Selected Proceedings from the Canadian Society for Eighteenth-Century Studies

\section{Samuel Johnson, Periodical Publication, and the Sentimental Reader: Virtue in Distress in The Rambler and The Idler}

\section{Chance David Pahl}

Volume 36, 2017

URI : https://id.erudit.org/iderudit/1037852ar

DOI : https://doi.org/10.7202/1037852ar

Aller au sommaire du numéro

Éditeur(s)

Canadian Society for Eighteenth-Century Studies / Société canadienne d'étude du dix-huitième siècle

ISSN

1209-3696 (imprimé)

1927-8284 (numérique)

Découvrir la revue

Citer cet article

Pahl, C. D. (2017). Samuel Johnson, Periodical Publication, and the Sentimental Reader: Virtue in Distress in The Rambler and The Idler. Lumen, 36, 21-35.

https://doi.org/10.7202/1037852ar 


\section{Samuel Johnson, Periodical Publication, and the Sentimental Reader: Virtue in Distress in The Rambler and The Idler}

Chance David Pahl

University of Ottawa

Like many of the essay serials and magazines published in mid eighteenth-century England, Samuel Johnson's Rambler (1750-52) and Idler (1758-60) contain numerous melancholy tales of "virtue in distress." Young women who have lost health, wealth, or innocence reach out to Johnson's eidolons for the reader's benefit or their own relief. Despite being linked to the growing market for sentimental literature, Johnson's periodical portrayals of victimized women are notable for their lack of pathos. In this paper I will suggest that this lack is deliberate. Though these epistles do bear some resemblance to the popular literature of sensibility, their focusing on generic personae rather than specific individuals, their privileging of bare description over tragic declamation, and their disguising of the heroines' emotions distance them from such literature. Equally important, Johnson's tales of virtue in distress tend towards poetic justice and the deflation of strong emotions. Johnson's rationale for limiting the pathos of these stories is multifaceted, but an overlooked reason has to do with his awareness of the difficulty of raising powerful feelings in short, miscellaneous works. In this, Johnson concurs with contemporary theorists such as Adam Smith, who would go on to state in his Lectures on Rhetoric and Belles Lettres (1762-63) that "smaller compositions ... have not time nor

I would like to thank April London, Frans De Bruyn, and the two anonymous Lumen readers for their perceptive comments on early drafts of this essay. 
connexion Sufficient to awaken great emotions." Instead of avoiding tragic spectacles altogether, however, Johnson makes virtue of necessity by arguing that the most affecting tales are seldom the most useful. ${ }^{2}$ Unlike obviously sentimental works of literature, Johnson's tales do not agitate the passions, but neither do they inhibit the reader's reformation because of their improbability. Johnson's curiously muted tales of virtue in distress thus reflect his desire to turn perceived weaknesses of periodical publication into strengths, and, more generally, to solidify the important place of miscellaneous literature in the eighteenthcentury literary field.

When not avoided by critics altogether, Samuel Johnson's female correspondents in The Rambler and The Idler have frequently been approached from a gender studies perspective. Scholars such as Lorraine Eadie, Sarah Morrison, and James Basker have shown how Johnson's fictional letters from women in the periodicals shed light on his relatively "progressive" attitude towards real women, thus challenging the longstanding perception of Johnson as a misogynist. ${ }^{3}$ While valuable, these studies tend to focus on Johnson the man rather than Johnson the writer, and thus tell only part of the story. Johnson's female fictions do expose the myth of his misogyny, but, when read with an eye to literary-historical context, they also show him to be a shrewd literary projector. As I will go on to suggest, Johnson's periodical portrayals of distressed women, in particular, should be read in the context of the eighteenth-century demand for sentimental literature, a demand that miscellaneous writers such as Johnson - perennial underdogs in the early modern literary field - met in innovative ways.

is it is

1. Adam Smith, Lectures on Rhetoric and Belles Lettres (Indianapolis: Liberty Fund, 1985), 126.

2. Samuel Johnson, The Rambler, ed. W.J. Bate and Albrecht Strauss, vols. 3-5 of The Yale Edition of the Works of Samuel Johnson (New Haven: Yale UP, 1969), 5: 320. Hereafter cited parenthetically.

3. See Lorraine Eadie, "Johnson, the Moral Essay, and the Moral Life of Women," Age of Johnson 21 (2011), 21-42; Sarah Morrison, "Samuel Johnson, Mr. Rambler, and Women," Age of Johnson 14 (2003), 23-50; and James Basker, "Dancing Dogs, Women Preachers and the Myth of Johnson's Misogyny," Age of Johnson 3 (1990), 63-90. 
The eighteenth-century demand for sentimental literature is obvious enough, though the connection between such literature and the figure of the distressed woman needs some clarification. Admittedly, sentimental literature is a broad and at times amorphous category: for the purposes of this argument, it is enough to say that its defining characteristic was "the arousal of pathos through conventional situations, stock familial characters and rhetorical devices," and that it was in many ways a response to the emergence of a reading audience eager for "empathetic role playing." "As Trevor Ross states, eighteenthcentury authors were increasingly aware of, and responsive to, "readers, their judgment, expectations and requirements." Because the arousal of pathos was a key goal of sentimental literature, images of suffering or distress were bound up with this tradition, though it is important to remember that the distressed individuals in sentimental literature had little in common with the larger-than-life heroes of Greek tragedy. As Mikhail Bakhtin observes, the literature of sensibility was predicated on "a pathos occasioned by helplessness and weakness rather than by heroic strength." Specifically, sentimental texts often relied on depictions of female virtue in distress in order to elicit an emotional response on the part of the reader. While male virtue in distress was a possibility - witness Henry Mackenzie's Man of Feeling (1771) - the popular perception of women as innately or extremely vulnerable, particularly to the sexual advances of men, meant that the distressed individuals in sentimental tales tended to be "archetypically female."7 Eighteenthcentury aesthetic theorists were aware of, and repeatedly stressed, the emotive power of the distressed woman figure. As early as 1712, Joseph Addison had argued that an accurate rendering of a "beautiful face ... softened with an Air of Melancholy or Sorrow" had the ability to "raise a secret Ferment in the Mind of the Reader, and to work, with Violence,

4. Janet Todd, Sensibility: An Introduction (London: Methuen, 1986), 2; Reinhard Wittmann, "Was there a Reading Revolution at the End of the Eighteenth Century?," in A History of Reading in the West, ed. Guglielmo Cavallo and Roger Chartier (Amherst: Massachusetts UP, 1999), 300.

5. Trevor Ross, “The Emergence of 'Literature': Making and Reading the English Canon in the Eighteenth Century," ELH 63.2 (1996), 406.

6. Mikhail Bakhtin, The Dialogic Imagination (Austin, TX: U of Texas P, 2008), 397.

7. G.J. Barker-Benfield, The Culture of Sensibility: Sex and Society in EighteenthCentury Britain (Chicago: Chicago UP, 1992), 219. 
upon his Passions." ${ }^{8}$ Later critics agreed. Significant in this regard was Henry Home, Lord Kames, who singled out this image when formulating his concept of "ideal presence," suggesting that portrayals of distressed women were capable of sweeping away the observer in a kind of "reverie." Kames admits that he himself slipped into just such a waking dream when meditating on the sight of "a beautiful woman in tears for the loss of an only child." Of course, one need not have actually seen a beautiful woman in tears to imagine such a figure, and Kames is quick to point out that an imaginative, albeit convincing, literary depiction of the rape of Lucretia would serve the same purpose (ibid., 1: 71). Kames's quasi-phenomenological analysis goes a long way towards explaining why distressed women were such an integral part of the literature of sensibility: by raising the emotions to a fever pitch, such images enabled the "sympathetic identification and even dreamy self-forgetting" craved by sentimental readers. ${ }^{10}$

Before proceeding, it is worth stressing that Johnson was not aloof from either the general culture of sensibility or its corollary, sentimental literature. As Robert Uphaus points out, Johnson was profoundly interested in the "affective appeal" of literature. ${ }^{11}$ Though reticent to discuss the subject at length - in an instructive reminiscence, Hester Piozzi admits that Johnson never liked to speak "of the pathetic in poetry"12 - Johnson was also conscious that some of the most affecting literature involved female virtue in distress. When commenting on Rowe's sentimental tragedy Jane Shore, Johnson bluntly states that it "lays hold upon the heart."13

It should not be surprising to find, therefore, that Johnson's periodicals contain numerous portrayals of virtue in distress, nor that these

8. Joseph Addison, Spectator no. 418 (30 June 1712), in The Spectator, ed. Donald F. Bond (Oxford: OUP, 1987; Oxford Scholarly Editions Online, 2014), 3: 567.

9. Henry Home, Lord Kames, Elements of Criticism, ed. Peter Jones (Indianapolis: Liberty Fund, 2005), 1: 67 .

10. Mark Salber Phillips, Society and Sentiment: Genres of Historical Writing in Britain, 1740-1820 (Princeton: Princeton UP, 2000), 106.

11. Robert W. Uphaus, The Impossible Observer (Lexington: U of Kentucky P, 1979), 7 .

12. Hester Lynch Piozzi, Anecdotes of the Late Samuel Johnson, LL.D (London: T. Cadell, 1786), 199, Eighteenth-Century Collections Online (CW3324803248).

13. Samuel Johnson, The Lives of the Most Eminent English Poets (London: Rivington and Sons, 1790), 2: 314, Eighteenth-Century Collections Online (CW3310485696). 
portrayals bear similarities to other, obviously sentimental works of fiction. In the first place, like more popular sentimental works, Johnson's tales of distress are domestic or private in scope. To eighteenth-century thinkers such as Adam Smith, such a focus was particularly calculated to encourage an emotive response on the part of the reader: as Smith explains in his Lectures, "the incidents of private life ... affect us more deeply and interest us more than those of a Publick nature," for "In Private calamities our passions are fixt on one, as it were concentrated." 14 Johnson would seem to agree, equating the domestic with the pathetic in both his Life of Rowe and his Life of Otway. ${ }^{15}$ Furthering their connection to the sentimental tradition in literature, Johnson's distressed women narratives feature exceptional protagonists. While the literature of sensibility was marked by an interest in characters "more ordinary than ideal,"16 the heroes and heroines of such literature were nevertheless often distinguished by some remarkable quality, bearing up Edmund Burke's broad claim in the Philosophical Enquiry (1757) that the most affecting narratives involve "some excellent person who sinks under an unworthy fortune." ${ }^{17}$ It is therefore significant that the sorrowful heroines in Johnson's periodicals, while not socially high ranking, nevertheless begin their narratives by emphasizing those qualities that elevate them above, or otherwise set them apart from, other women. Recalling her pampered existence before contracting smallpox, Victoria casually states in Rambler no. 130 that "I was born a beauty" and that all other women "fell below my perfection" in this regard (4: 326-27). Prior to her descent into prostitution, the young Misella in Rambler no. 170 is equally remarkable for her innocence (5: 136), and even the plebeian Betty Broom in Idler no. 26 is distinguished by her charity-school teachers for her academic precocity, at least until the school's closure drives her to London in search of menial

14. Smith, Lectures, 113 .

15. Regarding Jane Shore, Johnson says that "This play, consisting chiefly of domestic scenes and private distress, lays hold upon the heart” (Lives 2: 314). Speaking of Otway's Orphan, Johnson writes that "It is a domestick tragedy drawn from middle life. Its whole power is upon the affections" (Lives 1: 335).

16. Phillips, Society and Sentiment, 127.

17. Edmund Burke, A Philosophical Enquiry into the Origin of our Ideas of the Sublime and Beautiful (Notre Dame: Notre Dame UP, 1968), 46-47. 
employment. ${ }^{18}$ Other elements that link these tales to the sentimental tradition are, briefly, their epistolary format - making them appear, in Samuel Richardson's memorable phrase, written "to the Moment, while the heart is agitated by Hopes and Fears," 19 and thus ostensibly eliciting "sympathetic involvement" on the part of the reader ${ }^{20}-$ and a general air of realism, or rather, an absence of those fantastic and unbelievable elements associated with the romance or faerie traditions.

That being said - and this is the crux of my argument - Johnson's tales ultimately work against the prospect of a powerful emotive response on the part of the reader, upholding Iona Italia's claim that Johnson's essays "have little in common with the sentimental novels" of the period. ${ }^{21}$ To be sure, late eighteenth- and early nineteenthcentury commentators such as James Boswell, William Hazlitt, and Lord Macaulay never thought of these fictions as particularly affecting, in part because of the correspondents' latinate diction, a characteristic that, they implied, distracted from the pathos of the stories. According to Macaulay, "no man surely ever had so little talent for personation as Johnson": his heroines, like all his characters, speak "in a learned language - in a language which nobody hears from his mother or his nurse - in a language in which nobody ever quarrels, or drives bargains, or makes love - in a language in which nobody ever thinks." ${ }^{22}$

There is an element of truth to such assessments, but the tendency of critics to focus almost exclusively on the latinate speech patterns of Johnson's female correspondents, particularly as the nineteenth century wore on, has obscured the more fundamental ways that Johnson worked to interrupt empathetic identification on the part of his audi-

18. Samuel Johnson, "The Idler" and "The Adventurer," ed. John Bullitt, W. J. Bate and L. F. Powell, vol. 2 of The Yale Edition of the Works of Samuel Johnson (New Haven: Yale UP, 1963), 8o. Hereafter cited parenthetically.

19. Samuel Richardson, Sir Charles Grandison (Oxford: Oxford UP, 1986), 4.

20. Thomas Keymer, "Sentimental Fiction," in The Cambridge History of English Literature, 1660-1780, ed. John Richetti (Cambridge: Cambridge UP, 2005), 584.

21. Iona Italia, "Johnson as Moralist in the Rambler," Age of Johnson 14 (2003), 63.

22. Thomas Babington, Lord Macaulay, Lord Macaulay's Essays (London: Routledge, 1892), 195. In the same vein, Boswell writes that Johnson's language makes his female correspondents "seem strangely formal, even to ridicule." James Boswell, Life of Johnson (Oxford: OUP, 2008), 160. Hazlitt agrees, stating that Johnson's "Letters from Correspondents ... are more pompous and unwieldy than what he writes in his own person." William Hazlitt, Lectures on the English Comic Writers (New York: Dolphin, 1819), 144. 
ence. Significant in this regard is Johnson's tendency to privilege generalizations over particulars, a tendency, like others I will consider, that suggests his awareness, perhaps even anticipation, of emerging trends in eighteenth-century aesthetic theory. As the Dissenter Joseph Priestley observes in his Lectures on Oratory and Criticism (1777), "when general and abstract terms are used, the imagination must ... reduce them to particulars, before any real scene can be imagined, or any passion raised." ${ }^{23}$ It is true that Johnson tends to privilege the general over the particular in all his writings, but this alone does not account for the predominance of the one over the other in his tales of virtue in distress. Moreover, as Howard Weinbrot reminds us, Johnson was known to criticize excessive generality in literature and to stress the value of particularity, above all in his defence of biography. ${ }^{24}$ Clearly, then, Johnson's decision to privilege the general over the particular in these essays is significant, suggesting as it does a deliberate limiting of pathos.

The characters in Johnson's narratives of virtue in distress bear out this claim. This is not to suggest that they are entirely abstract - simply that they are frequently unnamed, possess general titles, generic names, or are lumped into broad categories. The name of Misella, the prostitute in Rambler nos. 170 and 171, is noteworthy in this regard, being simply the feminine form of the Latin adjective meaning "poor" or "wretched." It is worth recalling that Johnson had used the same adjective in its masculine form in Rambler no. 16, this time to describe an unfortunate author, Misellus. Johnson's use of such names suggests that Misella and Misellus are more a type of character in the manner of Theophrastus or, to some extent, La Bruyère, than they are specific

23. Joseph Priestley, A Course of Lectures on Oratory and Criticism (New York: Garland, 1971), 84. Of course, as Ann Jessie Van Sant points out, none of this is particularly new: "In his treatise on the soul, Aristotle explains that the particular moves the passions more effectively than the universal. In the Rhetoric, he explains the necessity of 'actualizing' an object, of setting it 'before the eyes' of an audience. Particularity is the writer's means of creating images, and thus of turning readers into spectators." Ann Jessie Van Sant, Eighteenth-Century Sensibility and the Novel (Cambridge: Cambridge UP, 1993), 28.

24. Howard D. Weinbrot, "The Reader, the General, and the Particular: Johnson and Imlac in Chapter Ten of Rasselas," Eighteenth-Century Studies 5.1 (1971), 89, 92. As Johnson writes in Rambler no. 60, those "images, to which we readily conform our minds are ... to be found in narratives of the lives of particular persons" (3: 319; my emphasis). 
individuals. ${ }^{25}$ His use of the appellation Perdita or "lost one" in both Idler no. 42, a dismal tale in which the heroine is "tricked out for sale" by her father (133), and Adventurer no. 74, wherein the protagonist's pursuit of "a husband of rank and fortune superior to my own" is stymied by a superfluity of advice (398), drives home this point. Curiously, while the names of Johnson's distressed women often suggest only a generic persona, their persecutors are rarely named at all: in Rambler no. 12, Zosima, the unfortunate daughter of a bankrupt country gentleman, refers to her cold-hearted London relative simply as "my relation" (3: 62), and Misella describes her seducer in the same way. Priestley emphasizes the significance of such general titles when he states that the writer who would affect his reader should "prefer a more particular to a more general term; as father, mother, brother, sister, \&c. instead of relation." ${ }^{26}$ Other persecutors lack a definite identity to the extent that they can be lumped into categories of genus or sex: thus Misella describes her clients simply as "despicable wretches" and "reptiles" (Rambler 5: 139); and Victoria distinguishes those who mistreat her only in terms of their sex (Rambler 4: 343). This lack of characterization reflects an absence of psychological development, but also, more importantly, works against the likelihood of the reader's being moved by Johnson's melancholy female correspondents.

If a lack of characterization is designed to prevent the reader from conceiving a clear image of the women in question, and therefore from viewing them with any degree of emotion, the women's own tendency to race through those parts of their narratives that would seem most affecting is calculated to be equally disruptive of pathos. In this, Johnson once again demonstrates his awareness of emerging trends in aesthetic theory, if only by reversing prescriptions for raising the pas-

25. As Marie Hamilton Law stresses in her classic study of the English familiar essay, La Bruyère's "English predecessors had created types which by means of much witty ingenuity, they endowed with attributes which enabled an individual to recognize himself in the type, but La Bruyère made his readers believe in the individuality of the characters he typified." Marie Hamilton Law, The English Familiar Essay in the Early Nineteenth Century (New York: Russell and Russell, 1965), 79.

26. Priestley, A Course of Lectures, 86; my emphasis. Priestley goes on to state that such a writer should also prefer specific terms such as "justice, temperance, veracity, $\& c$. and cruelty, covetousness, deceit, \&c. as the case requires, instead of the more indefinite terms virtue, and vice; and universally, the proper names of persons, places, and things, rather than more comprehensive terms which are applicable to other ideas besides those ... intended to be conveyed" (ibid.). 
sions put forward by eighteenth-century theorists. As Lord Kames would go on to observe in his monumental Elements of Criticism $(1762)$, "it is necessary that the cause of every emotion be present to the mind a due time; for an emotion is not carried to its height but by reiterated impressions." ${ }^{27}$ As indicated, such reiterated impressions are conspicuously lacking in Johnson's tales of virtue in distress. One has only to read Betty Broom's unhappy history in The Idler to realize that Johnson's narratives of distressed women are often remarkably fastpaced: in these essays, one tragic situation gives way to another, with the repetitive insertion of the transitioning adverb "then" precluding any possibility of reflection (e.g., "I then lived with a gentlewoman of a small fortune," "I then fled for refuge to the other end of the town," "I was then hired by a consumptive lady") (90-91). Zosima's sad tale in Rambler no. 12, in which the protagonist races from one interview to the next, is similarly fast-paced. As such, when potentially pathetic events are described, they generally take the form of short, bare descriptions.

Perhaps more importantly, Johnson's victimized women rarely show their own emotions, either to their persecutors or to the periodical eidolon. This is significant as, according to mid-century theorists such as Adam Smith, "no action however affecting in itself, can be represented in such a manner as to be very interesting ... by a bare narration where it is described directly without taking notice of ... the effects it had on those who were either actors or spectators of the whole affair." ${ }^{28}$ Admittedly, none of Johnson's periodical correspondents come across as particularly emotional. Yet such reticence is striking when one considers the degree of distress Johnson's female correspondents labor under. Remarkably, some of Johnson's distressed women appear not even to feel grief over their losses. Following the "failure of a fund, in which my money was placed," the suddenly-penniless Melissa observes in Rambler no. 75 that "I bore the diminution of my riches without any outrages of sorrow, or pusillanimity of dejection" (4: 30). Most, though, simply hide their feelings: after contracting smallpox, Victoria states that she did not gratify her acquaintance with "any appearance of resentment or depression" (Rambler 4: 344); and when she is literally

27. Lord Kames, Elements, 1: 70.

28. Smith, Lectures, 86. 
"depressed" by her relations, Misella locks herself away "to vent my grief" (Rambler 5: 137). Moreover, while a few female correspondents do see Johnson's periodicals as a legitimate outlet for their emotions - Molly Quick, the waiting maid in Idler no. 46 who is terrorized by her employer's "odd humour," states that she must vent her "vexation" to the Idler because if she does not she will "burst" her silence to her mistress (143) - most hide them from the reader as well. Upon the death of a kind employer in Idler no. 29, Betty Broom writes, "I shall say no more than that her servant wept upon her grave" (91); and after being expelled from her home, Misella says that the "rage, anguish, and resentment, which I felt ... are not to be expressed" (Rambler 5: 142). In this last case, Misella's professed inability to communicate her feelings to the reader should not be taken as a form of adynaton, a rhetorical device used to emphasize the horror of a situation by calling attention to the impossibility of expression. ${ }^{29}$ The truth is that Misella is not only unable to communicate her feelings, but unwilling to do so even if it were possible, as the rest of her narrative makes clear. Kathleen Kemmerer sums up this aspect of the tales nicely when she states that Johnson's female personae never "report their emotional reactions to events," and almost always speak in an "emotionally understated style." 30

To this point, I have focused primarily on those stylistic elements of Johnson's stories of virtue in distress that limit their pathetic appeal. Yet there are other, more general aspects, in terms of plot and narrative progression, that do the same. Significantly, Johnson's periodical essays rarely feature sexual victimization, a trump-card of sentimental literature. To be sure, the events recorded are sufficiently calamitous, and the threat of sexual victimization is often present. ${ }^{31}$ But such fears

29. Silva Rhetoricae, s.v. "Adynaton," http://rhetoric.byu.edu.

30. Kathleen Kemmerer, "A Neutral Being Between the Sexes": Samuel Johnson's Sexual Politics (Lewisburg: Bucknell UP, 1998), 82, 85. Carey McIntosh's observation regarding Rambler nos. 170 and 171 is generally applicable here: to McIntosh, Misella's story is "curiously muffled, not weepy at all," in large part because of the focus on circumstances rather than feelings. Carey McIntosh, The Choice of Life: Samuel Johnson and the World of Fiction (New Haven and London: Yale UP, 1973), 160.

31. Zosima's relation, for example, talks of "sending me down in the wagon to preserve me from bad courses" (Rambler 3: 67); and in the Idler, Perdita is afraid that the "track" which she is on may lead her "at last to ruin" (132). This is not to discount the fact that there is, at times, a bathetic aspect to these fictions: Molly Quick's fear in Idler no. 46 is not that she will be forced into a life of prostitution if she displeases 
seldom come to fruition. Characteristic in this regard is Betty Broom's observation in The Idler, following her journey to the metropolis, that "I had no snares laid for me at my arrival but came safe to the sister of my mistress," a narrative turn that interrupts the reader's horizon of expectations (81). In fact, there is a general trend towards poetic justice in these essays. "Redeemer" figures repeatedly emerge to rescue women who have suffered one catastrophe and are in danger of suffering a worse. The numinous Euphemia appears at the conclusions of Rambler nos. 12 and 133 to rescue Zosima and Victoria, respectively, either by providing financial assistance or good advice; and in Idler no. 29, Betty Broom is suddenly extricated from her problems when a consumptive lady "died and left me five hundred pounds" (92). The list could go on.$^{33}$ Even Misella the prostitute ends her tale with the optimistic hope that she will be deported to the colonies, a circumstance that would restore her to "honesty and peace" (Rambler 5: 145).

There are a number of equally plausible reasons that could be put forward as to why Johnson shies away from presenting pathetic "pictures of life" in his periodicals, including a general distrust of imagination - expressed most vividly, perhaps, in the mad astronomer chapters of Johnson's novella Rasselas - or a more pointed dislike of emotionalism. In 1769, after all, Johnson roundly criticized those very "sensible" individuals who weep over the misfortunes of others, but show no interest in alleviating their sufferings: "You will find these very feeling people are not very ready to do you good. They pay you by

her employer, but that her mistress will "perhaps give the next gown to the housekeeper" (146).

32. For more on Johnson and poetic justice see Joan Klingel, "Reconciling Johnson's Views on Poetic Justice," Rocky Mountain Review of Language and Literature 37.4 (1983), 195-205.

33. "Miss Maypole," oppressed by her mother, is defended by a "maiden sister of my father" (Rambler 3: 298); Melissa discovers that she has two unexpected friends in "an old curate" and a "lieutenant of dragoons" (Rambler 4: 32); and Perdita in Idler no. 42 is encouraged by a "pious relation" who bids her "fly" to heaven for protection (134). 
feeling." ${ }^{4}$ Such reasons are certainly not wrong, though an analysis of Johnson's tales of virtue in distress that stops here would nevertheless be incomplete, failing as it would to take into consideration the constraints of periodical publication.

As such, I suggest that an equally important, and even fundamental, reason for Johnson's reticence to attempt moving narratives of distressed women in his periodicals is simply that truly affecting narratives require, or were thought to require, a great deal of uninterrupted space. To put it another way, short, miscellaneous pieces were seen as incapable of raising readers' emotions to what Lord Kames referred to as a "due pitch," unlike longer, more uniform works. ${ }^{35}$ As Adam Smith observes in his Lectures, "Great Passions as they are long of being raised in the Persons themselves so are they not to be raised in us but by a work of considerable Length." 36 Smith goes on to state that "A temper of mind that differs very little from the common tranquility of mind is what we can best enter into, by the perusal of a piece of a small length" (ibid.). More importantly, as Johnson himself argued, pathetic emotions are easily interrupted by the unexpected insertion of an incongruous idea. In his Life of Cowley, Johnson observes that the metaphysical poets were incapable of raising their readers' emotions as they tended to privilege the "unexpected and surprising," and had "no regard to that uniformity of sentiment which enables us to conceive and to excite the pains and the pleasure of other minds. ${ }^{\text {"37 }}$ While the comparison should not be pushed too far, miscellaneous periodical literature is similar to metaphysical poetry in the sense that both combine the "most heterogeneous ideas" in a larger whole (Rambler 1: 30) - though periodicals frequently do so on a number of different levels, in terms of both content and form. In Rambler no. 158, Johnson defines the essay, a literary mode or genre with close ties to periodical publication, as a "licentious" combination of material drawn from the author's mind and heaped together "without order, coherence, or propriety"

34. Boswell, Life of Johnson, 417. For more on Johnson's distrust of imagination see John Radner, "Samuel Johnson, the Deceptive Imagination, and Sympathy," Studies in Burke and His Time 16 (Fall 1974), 23-46. A discussion of Johnson's dislike of emotionalism can be found in Leopold Damrosch, Samuel Johnson and the Tragic Sense (Princeton: Princeton UP, 1972).

35. Lord Kames, Elements, 1: 212.

36. Smith, Lectures, 126.

37. Johnson, Lives, 1: 30. 
(5: 77); and in Idler no. 40 he puts his finger on a more general lack of coherence in many periodicals, lamenting the proximity of his didactic leaders to the frivolous advertisements of a commercial society: "The noblest objects may be so associated as to be made ridiculous" (126). Unable to maintain that "uniformity of sentiment" which is a prerequisite of empathetic identification, the periodical writer is thus at a clear disadvantage when it comes to tragic spectacles.

And yet, rather remarkably, Johnson does not shy away from such spectacles altogether, but instead works to convince his readers of the utility of melancholy fictions that do not agitate the passions unduly. As Paul Keen reminds us, "it is worth remembering the energy with which some writers made a virtue of necessity." 38 The didactic nature of literature is at the root of Johnson's defence, a didacticism that depends on mimesis or the "verisimilitude" of the object being represented. ${ }^{39}$ The problem, as Johnson sees it, is that the characters and events in pathetic literature are often too fantastic to credit, and "what we cannot credit we shall never imitate" (Rambler 3: 24). In his final Rambler essay, Johnson argues that as comic characters and scenes become more humorous and tragic characters and scenes more pathetic, "The mind of the reader is carried away from the contemplation of his own manners; he finds in himself no likeness to the phantom before him; and though he laughs or rages, is not reformed" (5:320). Put bluntly, Johnson's own tales may not move readers, but obviously pathetic literature does not always teach them anything because it is unnatural, and, therefore, unbelievable. In this way, the rather muted or muffled quality of Johnson's tales of virtue in distress could actually be said to work in their favour, emphasizing as it does their verisimilitude and thus ensuring their applicability.

This is not to suggest that Johnson's defence is entirely convincing. For example, theorists such as Lord Kames would presumably counter that pathetic literature must maintain an air of reality - that is, such texts must conform to "the order and course of nature" - for an

38. Paul Keen, Literature, Commerce, and the Spectacle of Modernity, 1750-1800 (Cambridge: Cambridge UP, 2012), 163.

39. The Penguin Dictionary of Literary Terms and Literary Theory, $4^{\text {th }}$ ed., s.v. "mimesis." 
"improbable incident" disrupts ideal presence. ${ }^{40}$ Moreover, by making this defence Johnson opens himself up to the charge that his own heroines are not always as believable as they could be, and that poetic justice is generally found in poems rather than in real life. The point I would like to stress, however, is simply that Johnson could be said to anticipate the charge that would be levelled against his periodical tales of virtue in distress by calling into question the merits of obviously or excessively pathetic literature.

In the end, Johnson's periodical fictions of virtue in distress should be thought of both as a product of the eighteenth-century demand for sentimental literature - included in The Rambler and The Idler to appeal to a growing body of sentimental readers hungry for such spectacles - and as an anomaly in terms of such literature. With their privileging of generic personae or "types" their tendency to gloss over affecting scenes, and their general drive towards poetic justice, Johnson's tales are curiously unlike other, obviously pathetic portrayals of virtue in distress. As indicated, this lack of pathos should be understood in light of the constraints of periodical publication, though this did not stop Johnson, and other periodical essayists like him, from printing melancholy tales of victimized women. In fact, such tales abound in mid eighteenth-century English periodicals, a reflection of the fact that periodical writers were comfortable and capable of making virtue of necessity. To be clear, I am not suggesting that all eighteenth-century periodical writers conceived of the constraints of periodical publication in exactly the same way, or reacted to them uniformly. Tales of virtue in distress in mid-century periodicals such as The Female Spectator (1744-46) and even The Adventurer (1752-54), to which Johnson was a contributor, bear closer affinities to obviously sentimental works than those found in The Rambler and The Idler. Nor am I attempting to gauge how real readers of Johnson's periodicals actually appropriated these texts, recognizing, as Michel De Certeau puts it, that there is a "silent, transgressive, ironic or poetic" aspect of

40. Lord Kames, Elements, 1: 76. To Kames, "a chain of imagined incidents linked together according to the order of nature, finds easy admittance into the mind; and a lively narrative of such incidents, occasions complete images, or in other words ideal presence: but our judgement revolts against an improbable incident; and if we once begin to doubt of its reality, farewell relish and concern" (ibid.). 
reading that resists coercion. ${ }^{41}$ But these two qualifications do not, I believe, discount the point at hand: namely, that Johnson's tales of virtue in distress reflect the ingenuity and innovation with which periodical writers responded to the constraints of their form and the demands of a market-driven society.

41. Michel De Certeau, The Practice of Everyday Life (Berkeley: U of California P, 1984), 172. 